\title{
Synthesis of Stress Proteins in Rat Cardiac Myocytes 2-4 Days after Imposition of Hemodynamic Overload
}

\author{
C. Delcayre, J.-L. Samuel, F. Marotte, M. Best-Belpomme,“ J. J. Mercadier, and L. Rappaport \\ Institut National de la Santé et de la Recherche Medicale U. 127, Hôpital Lariboisière, 75010 Paris, France; \\ and Unité Associée 1135, Centre National Recherche Scientifique, Université Paris 6, 75005 Paris, France
}

\begin{abstract}
Isolated adult myocytes incubated with $\left[{ }^{35}\right.$ S]methionine were used to study the expression of proteins in the rat heart during the first 2 wk after either pressure or volume overload. In both models an early (2-4 d) and transient expression of three major stress proteins (heat shock protein [HSP] HSP 70, HSP 68, and HSP 58) was observed together with an increased synthesis of putative ribosomal proteins. Only traces of ${ }^{35} \mathrm{~S}$-labeled HSPs were detected in controls and sham-operated animals. The three stress proteins were identified by their migration in two-dimensional gels, by comigration with HSPs, which had been induced in myocytes by incubation at $41^{\circ} \mathrm{C}$ and immunoblot analysis using antisera directed against the $70-\mathrm{kD}$ protein. Immunohistochemical staining of HSP 70 in rod-shaped myocytes and detection by immunoblot showed that HSP 70 was equally present and distributed in both sham-operated and overloaded hearts, and provided no evidence for a subpopulation of myocytes acutely involved in the increased expression of HSP 70. It is suggested that the transient expression of HSPs that occurs during the early adaptation of the myocardial cells to overload could confer some degree of protection to the actively growing myocytes.
\end{abstract}

\section{Introduction}

Hemodynamic overload induces a cascade of adaptational events in cardiac myocytes that compensates for the increase in cardiac work. In rodents, after a few weeks, both multiplication of contractile units and shift in the expression of a series of proteins lead to an improved efficiency at the myocyte level (1).

Triggering the response to a pressure overload happens quickly. A stimulation of RNA polymerase in the rat heart (2) and the appearance of new polysomes in rabbit (3) are observed as early as $30 \mathrm{~min}$ after imposition of the pressure overload. The relative amount of $\beta$-isomyosin heavy chain mRNA increases after $24 \mathrm{~h} \mathrm{(4)}$ and the skeletal $\alpha$-actin mRNA expression is transiently observed $2-4 \mathrm{~d}$ after overload (5). The time to the peak of synthesis of total protein occurred at $\sim 4 \mathrm{~d}(6)$.

Address all correspondence to Dr. L. Rappaport, Institut National de la Sante et de la Recherche Medicale U.127, Hopital Lariboisiere, 41' Boulevard de la Chapelle, 75010 Paris, France.

Received for publication 9 March 1987 and in revised form 22 February 1988.

J. Clin. Invest.

(c) The American Society for Clinical Investigation, Inc.

0021-9738/88/08/0460/09 \$2.00

Volume 82, August 1988, 460-468
In addition, transient alterations in cellular remodelings, such as multiplication of mitochondria (7) and redistribution of microtubules and intermediate filaments (8), are observed during the first week after aortic stenosis. Response to volume overload has not been as well documented, but appears to be slower (6).

The study of the expression of total proteins in the early phase of cardiac hypertrophy has been hampered by the technical difficulties of labeling nonabundant proteins and of distinguishing proteins of myocytes from those originating from other cell types. With the aim of identifying potential signals between mechanical stretch and adaptative myocyte hypertrophy, we used experimental models of aortic banding or aortic insufficiency in the rat that progressively induce compensatory cardiac hypertrophy $(9,10)$. $\mathrm{Ca}^{2+}$-tolerant cardiac myocytes were isolated at short periods after overloading and were incubated with $\left[{ }^{35} \mathrm{~S}\right] \mathrm{methionine}$. The process used for the labeling of synthesized proteins proved to be sensitive enough to allow the detection of a large number of proteins on two-dimensional polyacrylamide gel patterns. Transient alterations in the pattern of protein synthesis were evidenced early after imposition of overload. We describe in this report that, among the proteins whose synthesis was modified, the expression of three "heat-shock proteins" (HSPs) ${ }^{1}$ was particularly prominent during this period. One of those, the $70-\mathrm{kD}$ protein, has been previously described as being expressed in the heart in response to severe stresses $(11-13)$. The heat-shock response is now known to be a rapid and transient reprogramming of cellular activities that ensures survival during the stress period, protects essential cell components against heat damage, and permits a rapid resumption of normal cellular activities during the recovery period (see for a review references 14, 15). This study provides evidence that the synthesis of HSPs is an early response of cardiac myocytes to hemodynamic overload.

\section{Methods}

\section{Chemicals}

Purified BSA was purchased from Behring, Marburg, FRG. BSA (fraction V, reagent grade) and fluorescein-conjugated goat anti-rabbit Igs were supplied by Miles Laboratories, Inc., Naperville, IL. Collagenase (EC 3.4.24.3.) was obtained from Boehringer, Mannheim, FRG, and DNase II from Sigma Chemical Co., St. Louis, MO.

RNase, $\left[{ }^{35} \mathrm{~S}\right]$ methionine $(1,300 \mathrm{Ci} / \mathrm{mmol})$, Amplify, biotinylated donkey IgGs, and horseradish peroxidase-conjugated streptavidin were from Amersham International, Les Ulis, France. Acrylamide, bisacrylamide, and 4-chloro-1-naphthol were obtained from Bio-Rad

1. Abbreviations used in this paper: AI, aortic insufficiency; $\mathrm{AS}$, aortic stenosis; HSP, heat-shock proteins; LC1, light chain 1. 

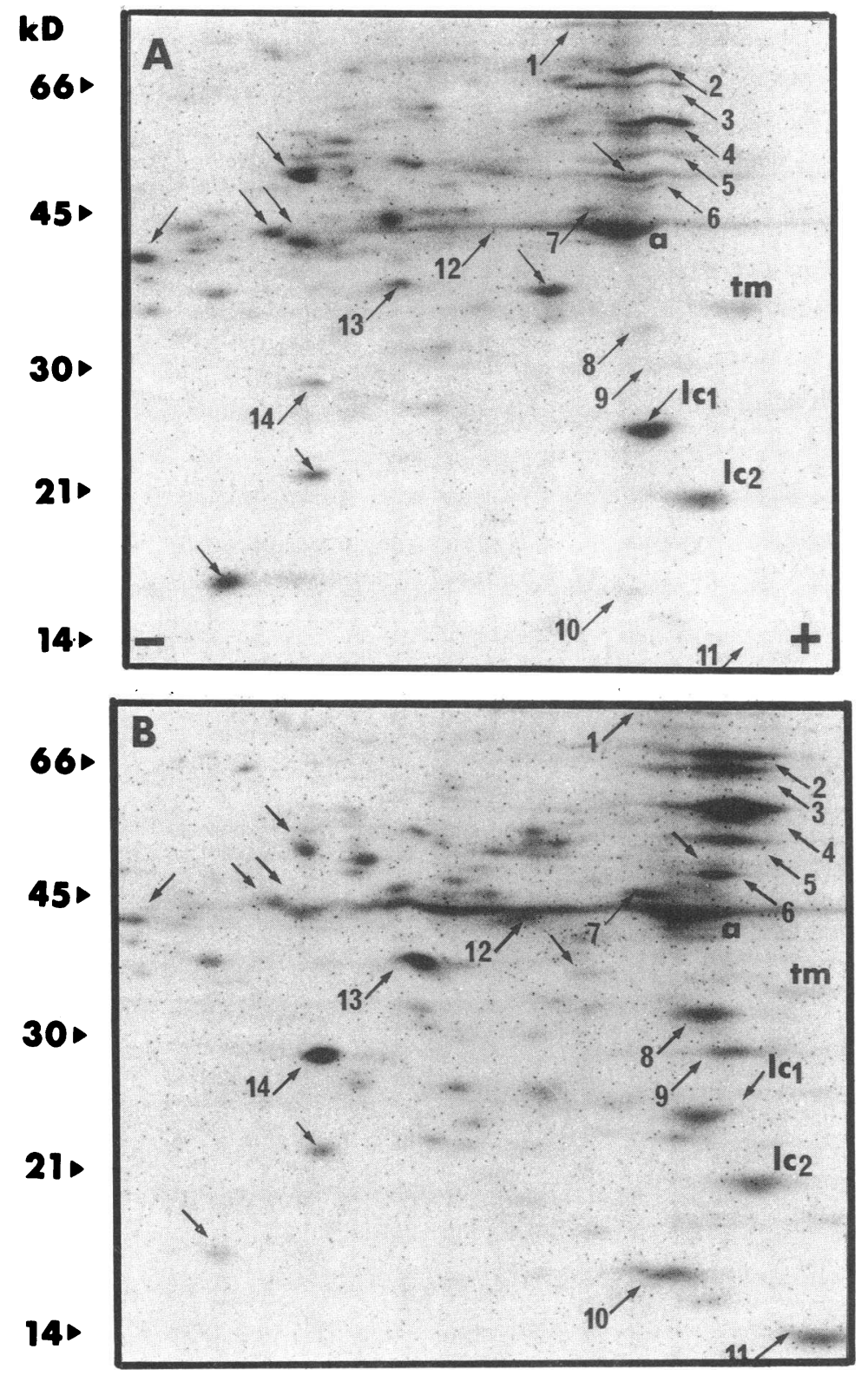

Figure 1. Pattern of acidic and neutral proteins in cardiac myocytes isolated from 3-wk-old rats $2 \mathrm{~d}$ after either sham operation $(A$ and $C$ ) or pressure overload ( $B$ and $D) .{ }^{35}$ S-labeled proteins were separated by two-dimensional nonequilibrium (2,400 V.h) ( $A$ and $B$ ) or one-dimensional polyacrylamide SDS gel electrophoresis ( $C$ and $D$ ) and were visualized by fluorography. SDS gels were linear and contained 10-20\% polyacrylamide. Equivalent amounts of radioactivity were loaded on paired gels. (B) Proteins whose synthesis was increased after aortic stenosis are indicated by numbered, upward pointing arrows. They respectively correspond to acidic proteins of $\mathrm{kD} 86$, $1 ; 70,2 ; 68,3 ; 58,4 ; 52$, $5 ; 49,6 ; 46,7 ; 34,8 ; 30$, $9 ; 17,10 ; 14,11$; and neutral proteins of $\mathrm{kD} 45$, $12 ; 39,13$; and $30,14$.

Those proteins whose synthesis was decreased are indicated by downward pointing arrows. (a, actin; tm, tropomyosin; $\mathrm{LC} 1$ and LC2, myosin light chains 1 and 2.) (C) The arrowheads indicate molecular weight standards. $(D)$ The * depicts proteins that are further analyzed in Fig. 2.
Laboratories, Rockville, NY, and Ampholines from LKB Instruments, Inc., Les Ulis, France. All other chemicals were analytical grade and obtained from Merck, Darmstadt, FRG.

\section{Experimental groups and surgical procedures}

Male Wistar rats (Iffacredo) were used throughout this study. The animals were provided with food (Extralabo M25 pellets) and tap water ad lib. Constriction of the aorta (AS) was performed by placing a clip around the ascending aorta in 3-wk-old rats (10). Aortic incompetence (AI) was induced in 8-wk-old rats by forcibly penetrating the aortic valves with a polyethylene catheter (9). Sham-operated controls underwent the same procedure except for the placement of the hemoclip or the penetration of the aortic valves. Cardiac hypertrophy was assessed by reference to heart weights of sham-operated rats of the same series. The measure of the degree of cardiac hypertrophy might be criticized since, in order to perform an adequate perfusion, the whole heart was weighed after a rather rudimentary dissection. Hypertrophy of myocytes was also assessed by calculation of the amount of protein per cell (Table I). Both indexes evidenced that hypertrophy was minimal after $2 \mathrm{~d}$, rose after $4 \mathrm{~d}$ and was significant after $7 \mathrm{~d}$.

\section{Isolation of myocytes}

Ventricular myocytes were isolated by the procedure of Eckel et al. with slight modifications (16). Briefly; rats were anesthetized with 0.15 $\mathrm{ml}$ of $6 \%$ sodium pentobarbital (Clin Midy) and the hearts were rapidly excised and placed in ice-cold, modified $\mathrm{KRB}$ ( $\mathrm{pH}$ 7.4) that contained $35 \mathrm{mM} \mathrm{NaCl}, 4.75 \mathrm{mM} \mathrm{KCl}, 1.19 \mathrm{mM} \mathrm{KH}_{2} \mathrm{PO}_{4}, 16 \mathrm{mM} \mathrm{Na}_{2} \mathrm{HPO}_{4}$, $25 \mathrm{mM} \mathrm{NaHCO}_{3}, 134 \mathrm{mM}$ sucrose, $10 \mathrm{mM}$ Hepes, and $10 \mathrm{mM}$ glucose. The whole heart was cannulated through the aorta on a Langendorff apparatus, and was perfused at $37^{\circ} \mathrm{C}$ for $3 \mathrm{~min}$ with $\mathrm{KRB}$ at a rate of $6 \mathrm{ml} / \mathrm{min}$, then for $40 \mathrm{~min}$ with the same buffer supplemented with $1 \mathrm{mg} / \mathrm{ml}$ collagenase and $5 \mathrm{mg} / \mathrm{ml}$ of purified BSA (fraction $\mathrm{V}$ ) at a rate of $2 \mathrm{ml} / \mathrm{min}$. Pressure of perfusion was $60 \mathrm{mmHg}$. After perfusion the ventricles were gently dissociated with forceps and incubated for 15 $\min$ in $15 \mathrm{ml}$ of the perfusion medium at $37^{\circ} \mathrm{C}$. The resultant dispersion was filtered through a nylon mesh and centrifuged for $4 \mathrm{~min}$ at 50 g. Cells were washed with $15 \mathrm{ml}$ of Hepes buffer ( $\mathrm{pH} \mathrm{7.4)} \mathrm{containing}$ $130 \mathrm{mM} \mathrm{NaCl}, 4.8 \mathrm{mM} \mathrm{KCl}, 1.2 \mathrm{mM} \mathrm{KH}_{2} \mathrm{PO}_{4}, 25 \mathrm{mM}$ Hepes, $5 \mathrm{mM}$ glucose, and $2 \% \mathrm{BSA}$ (fraction V). After gravity sedimentation, the cells were suspended in Hepes buffer containing $1.9 \mathrm{U} / \mathrm{ml}$ trypsin and incubated for $30 \mathrm{~min}$ at $37^{\circ} \mathrm{C}$. At the end of the incubation period 
Table I. Characterization of Myocyte Viability as a Function of Heart Hypertrophy

\begin{tabular}{|c|c|c|c|c|c|c|c|c|c|}
\hline \multirow[b]{2}{*}{ Time } & & & \multirow[b]{2}{*}{ Body weight } & \multicolumn{3}{|c|}{ Cell viability } & \multicolumn{2}{|c|}{ Index of hypertrophy } & \multirow{2}{*}{$\begin{array}{l}\text { Incorporation of } \\
{\left[{ }^{35} \text { S]methionine }\right.}\end{array}$} \\
\hline & & & & Yield* & $\% \operatorname{Rod}(1)^{*}$ & $\% \operatorname{Rod}(2)^{*}$ & & Heart weight & \\
\hline & & $n$ & $g$ & & & & $m g$ protein $/ 10^{6}$ cells & $m g$ & $c p m / \mu g$ protein \\
\hline \multirow[t]{2}{*}{ Day 2} & SH & (3) & $71 \pm 1$ & $3.2 \pm 0.4$ & $77 \pm 3$ & $73 \pm 6$ & $1.67 \pm 0.18$ & $396 \pm 12$ & $750 \pm 200$ \\
\hline & AS & (6) & $59 \pm 3$ & $2.5 \pm 0.3$ & $70 \pm 5$ & $57 \pm 6$ & $1.76 \pm 0.13$ & $444 \pm 15$ & $1,700 \pm 300^{8}$ \\
\hline \multirow[t]{2}{*}{ Day 4} & SH & (5) & $78 \pm 1$ & $3.0 \pm 0.8$ & $77 \pm 5$ & $69 \pm 4$ & $1.89 \pm 0.20$ & $424 \pm 25$ & $700 \pm 150$ \\
\hline & AS & (6) & $73 \pm 3$ & $2.8 \pm 0.3$ & $78 \pm 4$ & $59 \pm 4$ & $1.92 \pm 0.19$ & $516 \pm 21^{\prime \prime}$ & $1,200 \pm 400$ \\
\hline \multirow[t]{2}{*}{ Day 7} & SH & (3) & $90 \pm 2$ & $3.9 \pm 0.9$ & $84 \pm 0.1$ & $60 \pm 10$ & $1.87 \pm 0.09$ & $500 \pm 58$ & $930 \pm 150$ \\
\hline & AS & (3) & $85 \pm 4$ & $3.8 \pm 0.6$ & $83 \pm 2$ & $50 \pm 5$ & $2.77 \pm 0.3^{\S}$ & $723 \pm 67^{\S}$ & $524 \pm 150$ \\
\hline \multirow[t]{2}{*}{ Day 21} & SH & (4) & $183 \pm 10$ & $3.0 \pm 1$ & $86 \pm 1$ & $63 \pm 6$ & $2.84 \pm 0.53$ & $736 \pm 9$ & $968 \pm 100$ \\
\hline & AS & (4) & $207 \pm 25$ & $2.0 \pm 0.2$ & $70 \pm 5$ & $50 \pm 3$ & $5.12 \pm 0.06^{\|}$ & $1,390 \pm 157^{\prime \prime}$ & $530 \pm 200$ \\
\hline \multirow[t]{2}{*}{ Day 4} & SH & (2) & $219 \pm 6$ & $2.6 \pm 0.7$ & $88 \pm 2$ & $73 \pm 2$ & $2.78 \pm 0.26$ & $890 \pm 25$ & $333 \pm 100$ \\
\hline & Al & (3) & $213 \pm 8$ & $4.8 \pm 1$ & $81 \pm 2$ & $68 \pm 2$ & $2.92 \pm 0.44$ & $1,190 \pm 65^{\S}$ & $2,118 \pm 500^{8}$ \\
\hline
\end{tabular}

SH, sham-operated rats; AS, aortic stenosis; AI, aortic insufficiency. Values are means \pm SEM. ${ }^{*}$ Total number of cells per heart $\times 10^{6} .{ }^{\ddagger}$ Percent of rod-shaped cells before (1) and after (2) incubation. Significant differences are indicated as ${ }^{\S} P<0.05$; ${ }^{\prime} P<0.02$ from control value using Student's $t$ test.

soybean trypsin inhibitor was added and, after washing the cells in Hepes buffer, the purification of myocytes was achieved by two successive sedimentations in $10 \mathrm{ml}$ Hepes buffer. An aliquot of myocytes was counted in a Malassez chamber. Whatever the age or the physiological state of animals this method gave a yield ranging from 2 to $5 \times 10^{6}$ cells/heart (Table I).

Cell viability was assessed by determination of the percentage of rod-shaped cells before (1) and after (2) incubation (Table I), and on morphological criteria of intact cells (17); under phase contrast microscopy, rod-shaped myocytes were long and thin (see Fig. 7) and exhibited the typical alternating light and dark transverse banding. In accordance with Claycomb's conclusions (18), Trypan blue uptake was not considered a good test for cell viability but it was verified that the population of myocytes continued living for as long as $4 \mathrm{~d}$.

The myocytes were resuspended at a concentration of $1 \times 10^{6}$ cells $/ \mathrm{ml}$ in Hepes buffer and were maintained at $37^{\circ} \mathrm{C}$ in a shaking water bath. During the 90 -min period of incubation very few cells exhibited the square shape typical of anoxia (19). However, in some cases myocytes isolated from hypertrophied hearts were slightly more sensitive to incubation, as reflected by the increased number of cells that rounded during a period of $90 \mathrm{~min}$ (Table I).

\section{Heat shock}

After preincubation at $37^{\circ} \mathrm{C}$ for $30 \mathrm{~min}$, the myocyte suspension was divided into two parts; the first was incubated at the same temperature for $60 \mathrm{~min}$ and the second at $41^{\circ} \mathrm{C}$ for $60 \mathrm{~min}$. Both were then incubated at 37 or $41^{\circ} \mathrm{C}$, respectively, in the presence of $\left[{ }^{35} \mathrm{~S}\right]$ methionine, as described below.

\section{$\left[{ }^{35}\right.$ S $]$ Methionine labeling of myocytes}

Cells were incubated in $3 \mathrm{ml}$ Hepes buffer $\left(10^{6} \mathrm{cells} / \mathrm{ml}\right)$, maintained at $37^{\circ} \mathrm{C}$ for $60 \mathrm{~min}$, and further incubated with $\left[{ }^{35} \mathrm{~S}\right]$ methionine $(150$ $\mu \mathrm{Ci} / \mathrm{ml}$ Hepes buffer) for $30 \mathrm{~min}$. Incubations were terminated by the addition of $30 \mathrm{ml}$ ice-cold Hepes buffer without BSA. The cell suspension was centrifuged for 2 min in a Beckman L11 microfuge (Beckman Instruments, Inc., Palo Alto, CA) at 15,000 g. The pellet was frozen in liquid nitrogen and stored at $-70^{\circ} \mathrm{C}$ until use. In some experiments rounding of isolated myocytes was induced by a $1-\mathrm{h}$ preincubation at $43^{\circ} \mathrm{C}$. When incubated as above with $\left[{ }^{35} \mathrm{~S}\right]$ methionine these cells did not incorporate any radioactive label (not shown).

\section{PAGE}

Cells were lysed in $600 \mu \mathrm{l}$ of medium made of $0.3 \%$ SDS, $1 \% 2$-mercaptoethanol, $0.1 \%$ DNase, $0.2 \%$ RNase, $0.1 \mathrm{mM}$ PMSF, and homoge-
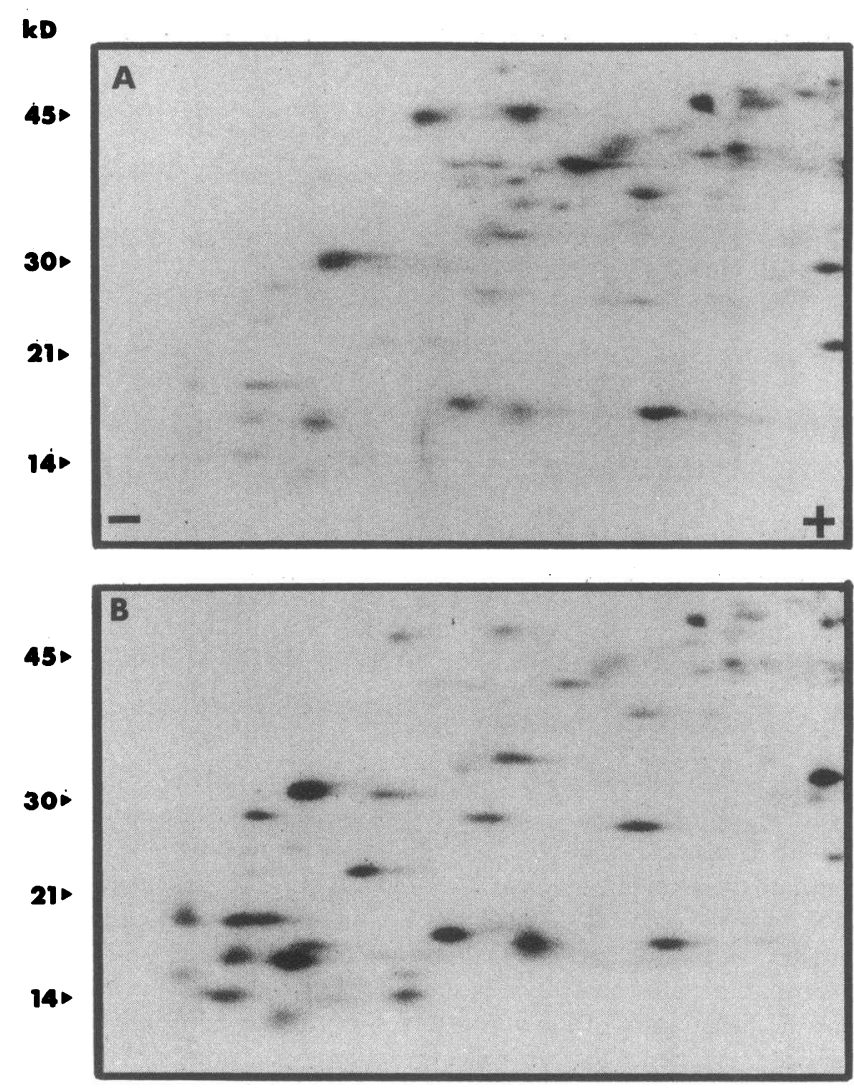

Figure 2. Patterns of basic protein synthesis in cardiac myocytes after pressure overload. ${ }^{35} \mathrm{~S}$-labeled proteins prepared from myocytes isolated $2 \mathrm{~d}$ after either sham operation $(A)$ or aortic stenosis $(B)$ were separated by nonequilibrium pH gradient $10-20 \%$ PAGE (1,000 V.h) and visualized by fluorography. 

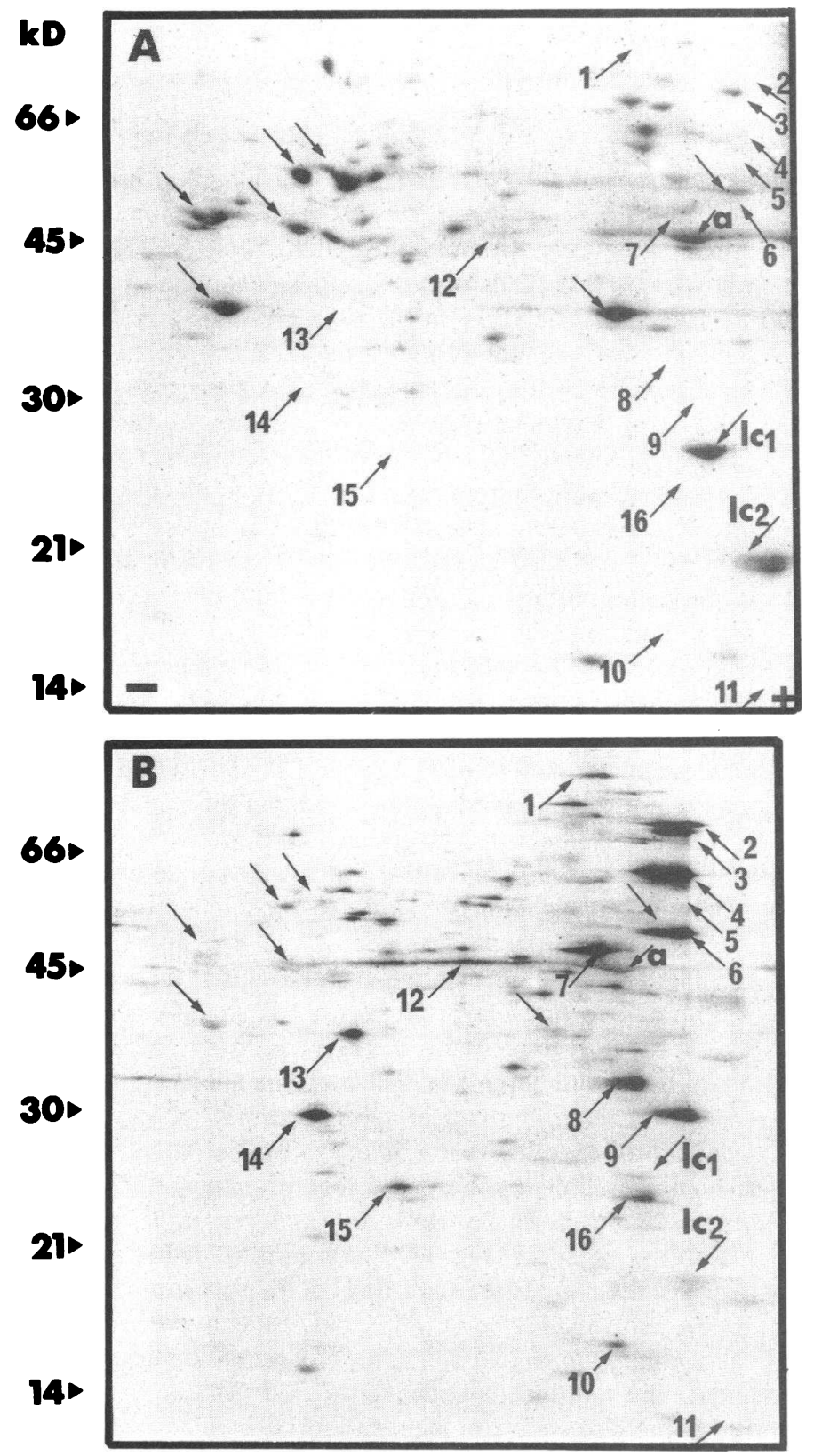

nized in a Dounce homogenizer for $15 \mathrm{~s}$ at $4^{\circ} \mathrm{C}$. Two aliquots of the lysate were respectively used for quantitation of both proteins (20) and radioactivity incorporated into TCA-precipitated proteins. Cell lysates were analyzed by one-dimensional gel electrophoresis on $5-10 \%$ or 10-20\% linear gradient SDS-polyacrylamide gels, according to Laemmli's method (21). Two-dimensional gel electrophoreses were performed using nonequilibrium electrofocusing in the first dimension as described by O'Farrell et al. (22). First dimension electrofocusing gels containing $0.4 \%$ of $\mathrm{pH} 5-8$ ampholines and $1.6 \%$ of $\mathrm{pH} \mathrm{3-10}$ ampholines were run for $2,400 \mathrm{~V}-\mathrm{h}$ to separate acidic and neutral proteins and for $1,000 \mathrm{~V}-\mathrm{h}$ to analyze basic proteins. Second dimension electrophoresis was carried out using $10-20 \%$ linear gradient SDS-polyacrylamide gels. Equal amounts of radioactivity were applied to each gel in an experimental group. Gels were prepared for fluorography with Amplify and exposed to Kodak XAR-5 film with amplifying screens at $-70^{\circ} \mathrm{C}$.

\section{Immunological procedures}

Polyclonal antibodies against chicken HSP 70 raised in rabbit were provided by Dr. Schlesinger (23).

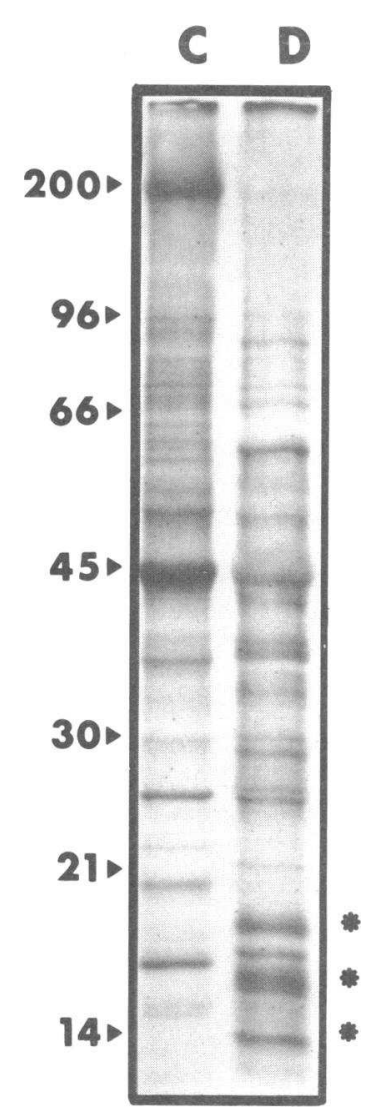

Figure 3. Pattern of protein synthesis in cardiac myocytes isolated from 8-wk-old rats 4 $\mathrm{d}$ after either sham operation $(A$ and $C$ ) or aortic insufficiency $(B$ and $D) .{ }^{35}$ S-labeled proteins were analyzed by fluorography as in Fig. 1 (same legend as in Fig. 1). The upward pointing arrow number 15 indicates a protein of $25 \mathrm{kD}$ only observed after AI.
Immunoblotting. Protein samples resolved by SDS-PAGE were electrophoretically transferred $\left(100 \mathrm{~V}\right.$ for $60 \mathrm{~min}$ at $\left.4^{\circ} \mathrm{C}\right)$ in $25 \mathrm{mM}$ Tris, $192 \mathrm{mM}$ glycine, $20 \%$ methanol, $\mathrm{pH} 8.3$, to nitrocellulose sheets according to the method of Towbin et al. (24). Blots were incubated for $1 \mathrm{~h}$ at $45^{\circ} \mathrm{C}$ in PBS, pH 7.6, containing $0.5 \%$ Tween 20 , washed four times in PBS containing $0.2 \%$ Tween 20, incubated for $1 \mathrm{~h}$ at $37^{\circ} \mathrm{C}$ with anti-HSP 70 antibodies $(60 \mu \mathrm{g} / \mathrm{ml})$, rinsed four times in PBS containing $0.2 \%$ Tween 20 , and then incubated for $1 \mathrm{~h}$ at room temperature with biotinylated donkey anti-rabbit Igs (1/300). After washing the blots, they were incubated with horseradish peroxidase-conjugated to streptavidin $(1 / 500)$ for $1 \mathrm{~h}$ at room temperature. Peroxidase binding was revealed by reaction with 4-chloro-1-naphthol.

Immunofluorescence. Two types of previously tested fixation procedures (25) were used. Briefly, myocytes were either first sedimented and then treated with methanol $\left(-20^{\circ} \mathrm{C}\right)$ for 6 min or treated with $1 \%$ Triton X-100 for 1 min before sedimentation and fixation with $3.5 \%$ formaldehyde.

Indirect immunofluorescence was performed as previously described (26). Cells were incubated for $30 \mathrm{~min}$ at $37^{\circ} \mathrm{C}$ with rabbit anti-HSP 70 antibodies $(60 \mu \mathrm{g} / \mathrm{ml})$ and, after they were washed, they 


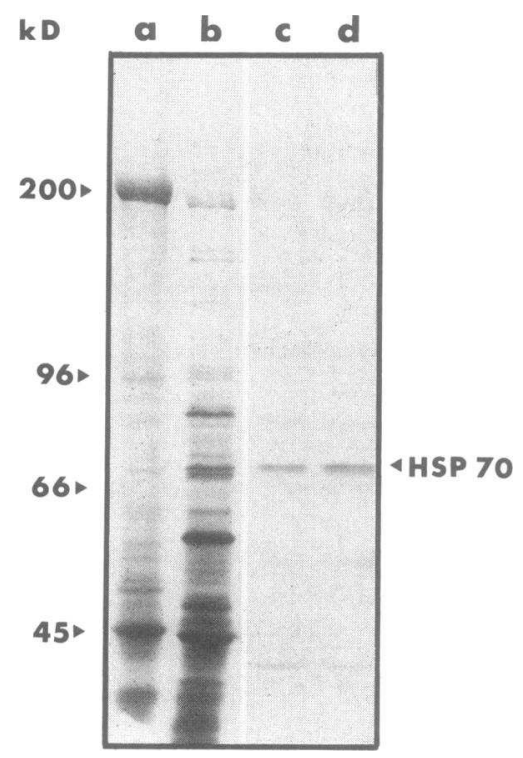

Figure 4. Immunological identification of the 70-kD stress protein in cardiac myocytes. Proteins from myocytes isolated $4 \mathrm{~d}$ after either sham operation ( $a$ and $c$ ) or volume overload ( $b$ and $d$ ) were labeled with $\left[{ }^{35}\right.$ S $]$ methionine and subjected to 5-10\% linear gradient acrylamide SDS-gel electrophoresis, which allows a better electrotransfer of the proteins. Gels were either fluorographed ( $a$ and $b$ ) or immunoblotted using anti-HSP 70 antibodies ( $c$ and $d$ ). Arrowheads indicate molecular weight standards. Lanes $a$ and $b$, identical amounts of radioactivity; lanes $c$ and $d$, identical amounts of proteins. Note that the antibodies revealed HSP 70 to be present in both extracts.

were incubated with fluorescein-conjugated goat anti-rabbit IgGs $(1 / 40)$. The control background of fluorescence was provided by incubating cells in the absence of anti-HSP 70 antibodies in the first step. Micrographs were taken with Kodak Tri-X Pan Film developed in Rodinal (Agfa).

\section{Results}

Protein synthesis during the early phase of cardiac overload. Protein synthesis was analyzed in cardiac myocytes isolated 2-15 d after either aortic stenosis or aortic insufficiency by incubating the cells for 30 min with $\left[{ }^{35} \mathrm{~S}\right]$ methionine (Table I). The cardiac response to overload was estimated using both the degree of cardiac hypertrophy and the amount of $\left[{ }^{35} \mathrm{~S}\right]-$ methionine incorporated into proteins (TCA precipitable expressed in counts per minute per microgram of protein) in myocytes isolated from overloaded hearts (AS or AI) and from controls. Despite variabilities, the levels of labeled amino acid that was incorporated (in counts per minute per microgram) were practically doubled after 2-4 d of AS, respectively, and even increased about eightfold after $4 \mathrm{~d}$ of AI.

Labeled proteins were analyzed by one- and two-dimensional gel electrophoresis.

Fig. 1 depicts results from protein extracts obtained $2 \mathrm{~d}$ after aortic stenosis. Fluorography of the gels, which measures pulse-labeled proteins and therefore is indicative of protein synthesis, showed that the synthesis of a series of proteins, among which myosin light chain 1 (LC1) was identified, was decreased. In contrast, synthesis of acidic proteins of 86,70 , $68,58,52,49,46,34,30,17$, and $14 \mathrm{kD}$ (respectively Nos. $1-11$ ) and neutral proteins of 45,39 , and $30 \mathrm{kD}$ (respectively Nos. 12-14) was markedly increased (Fig. 1, $A$ and $B$ ). Since two-dimensional gel electrophoresis was performed using a nonequilibrated $\mathrm{pH}$ gradient, precise determination of isoelectric points was not possible and positively charged polypeptides were excluded. These conditions were chosen for the high resolution of proteins obtained despite the large amount of proteins $(100-200 \mu \mathrm{g})$ layered onto the first dimensional gel. Comparison of Figs. 1, $C$ and $D$ revealed that aortic stenosis also induced a strong increase in the synthesis of a group of proteins with molecular masses between 14 and $30 \mathrm{kD}$. These proteins were analyzed using the electrophoretic conditions defined for basic proteins (Fig. 2). Their electrophoretic properties, $M_{\mathrm{r}}$ between 14 and $34 \mathrm{kD}$ and isoelectric $\mathrm{pH}$ over 9 , were similar to those described for ribosomal proteins $(22,27)$.

The relative increase in both the synthesis of acidic and putative ribosomal polypeptides and a decrease in the synthesis of proteins such as $\mathrm{LCl}$ appeared early after pressure overload. They developed progressively and were transient since they were observed in two out of six experiments $2 \mathrm{~d}$ after aortic stenosis, in four out of six after $4 \mathrm{~d}$, in one out of three after $7 \mathrm{~d}$, and were undetectable in experiments after 15-21 d. When overload was induced by aortic insufficiency, alterations in the pattern of protein synthesis were also observed but differed significantly from those observed after aortic stenosis (Fig. 3). In contrast with aortic stenosis, the labeling of myosin heavy chains, myosin light chains, and actin was almost completely inhibited (Fig. $3 \mathrm{D}$ ), and the synthesis of a group of acidic proteins of 52 (No. 5), 17 (No. 10), and 14 (No. 11) kD was not induced. However, the synthesis of the acidic proteins of $86,70,68,58,49,46,34$, and $30 \mathrm{kD}$ (respectively Nos. 1-4 and 6-9) (Fig. $3 \mathrm{~B}$ ) and of the group of basic low molecular weight proteins identified as putative ribosomal proteins (Fig. $3 D$ ) was strongly stimulated as observed after aortic stenosis (see Fig. 1 D). The time course of expression of these proteins was similar to that observed after aortic stenosis since they were transiently expressed $4 \mathrm{~d}$ after surgery (two experiments out of three) and never observed later (not shown).

Identification of stress proteins in cardiac myocytes. Labeled proteins synthesized in myocytes isolated $4 \mathrm{~d}$ after either a sham operation or volume overload were separated by onedimensional SDS-gel electrophoresis and were transferred to a nitrocellulose sheet (Fig. 4). Fluorography of the gels evidenced a large increase in synthesis of four proteins of $M_{\mathrm{r}} 86$, 70,68 , and $58 \mathrm{kD}$ (lane $b$ ). The $70 \mathrm{kD}$ protein reacted specifcally with the anti-HSP 70 stress protein antibodies (lanes $c$ and $d$ ) and was thus identified as the HSP 70. The 68-kD and 58-kD proteins were also identified as HSPs after comparison with the proteins expressed in myocytes subjected to a heat shock. Isolated myocytes heat shocked at $41^{\circ} \mathrm{C}$ for $60 \mathrm{~min}$ before a 30 -min incubation with $\left[{ }^{35} \mathrm{~S}\right]$ methionine at $41^{\circ} \mathrm{C}$ exhibited a $43 \pm 15 \%$ decrease in the incorporation of $\left[{ }^{35} \mathrm{~S}\right]-$ methionine into total proteins as well as alterations in the pattern of proteins synthesized (Fig. 5, $A$ and $B$ ). In contrast to the previous experiments, no alterations were observed in the synthesis of $\mathrm{LCl}$ and the putative ribosomal proteins. The main changes were the decrease in the synthesis of a series of neutral proteins with $M_{\mathrm{r}}$ of $40-80 \mathrm{kD}$ and a strong increase in the synthesis of three acidic proteins of $M_{\mathrm{r}} 70,68$, and $58 \mathrm{kD}$ (noted as HSP 70, HSP 68, and HSP 58 in Fig. 5 B). Comigration of the protein extracts from myocytes isolated $4 \mathrm{~d}$ after aortic stenosis (Fig. $5 \mathrm{C}$ ) and from heat-shocked myocytes (Fig. $5 \mathrm{~B}$ ) showed that among the proteins whose synthesis was stimulated by pressure overload, those of 70 (No. 2), 68 (No. 3), and 58 (No. 4) kD comigrated with the HSPs (Fig. 5 D).

Immunostaining of HSP 70 (Fig. 6) revealed that this protein was detected in all samples regardless of the overload inducer (pressure or volume), the time after surgery ( 2 or $15 \mathrm{~d}$ ) 

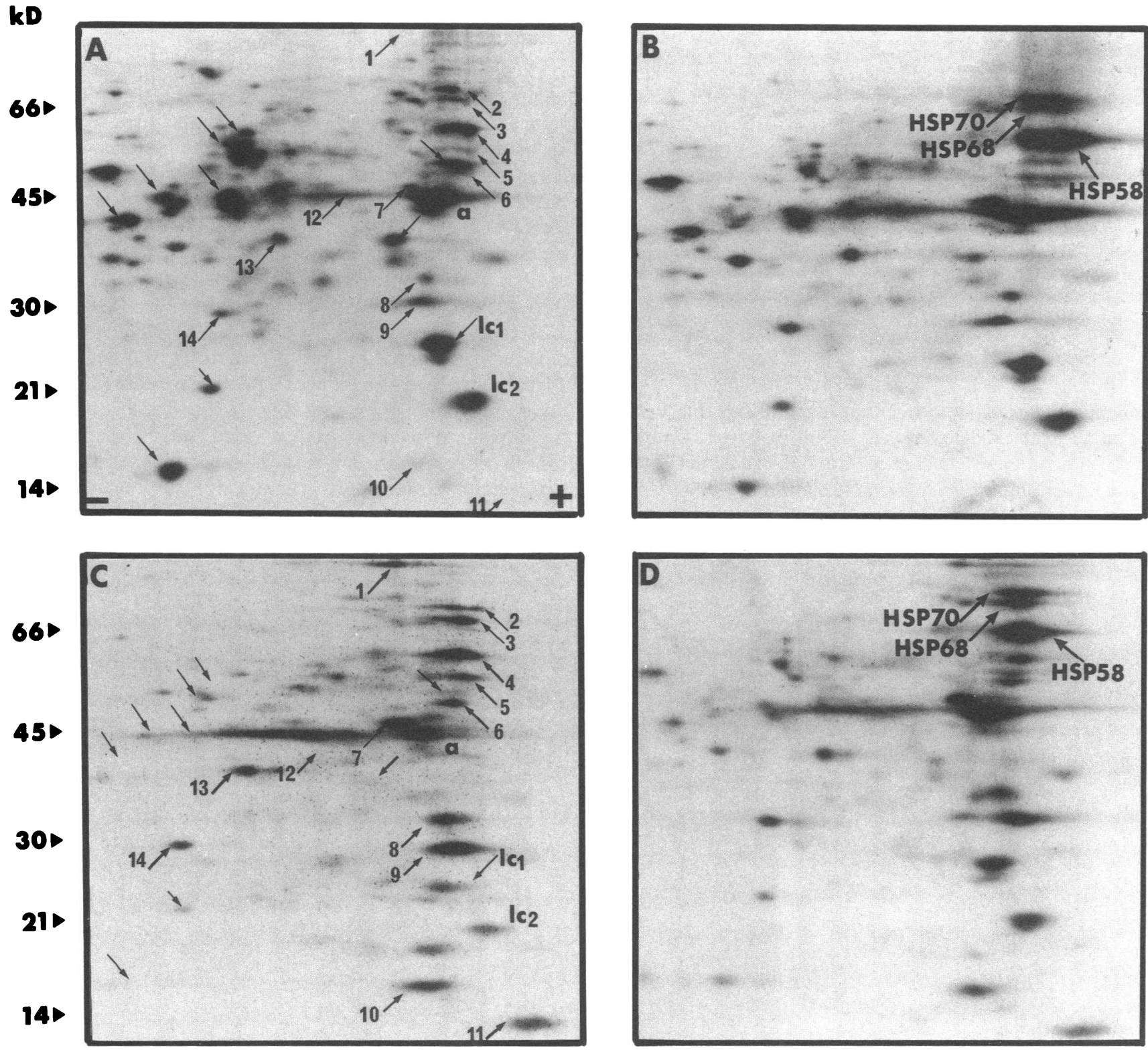

Figure 5. Characterization of HSPs in overloaded cardiac myocytes by their comigration with HSPs induced by thermal shock. ${ }^{35}$ S-labeled proteins were analyzed by fluorography as in Fig. 1. Extracts were from myocytes isolated either from normal rat $(A)$ submitted to a 90-min heat shock $(B)$ or $4 \mathrm{~d}$ after an aortic stenosis $(C)$. (D) An isovolumic mix of B and C (same legend as Fig. 1). Stress proteins of

$M_{\mathrm{r}} 70,68$, and $58 \mathrm{kD}$ (respectively Nos. 2, 3, and 4) in overload myocyte extracts were identified by their comigration with HSP 70, HSP 68, and HSP 58 induced by heat shock. Note that the patterns of protein synthesis in cardiac myocytes were almost identical 2 (Fig. $1 B$ ) and $4 \mathrm{~d}$ (this Fig. C) after pressure overload. Electrophoretic conditions are identical to those of Fig. 1.

(lanes $f$ to $j$ ), and the level of $\left[{ }^{35} S\right]$ methionine labeling of the protein (lanes $a$ to $e$ ). But the sensitivity of the method does not allow a quantitative evaluation of the relative accumulation of the protein. (lanes $f$ to $j$ ).

Immunofluorescent labeling of isolated myocytes was used to determine the distribution of HSP 70 (Fig. 7) in sham-operated and 4-d overloaded myocytes. In the two types of cells a diffuse fluorescent label was shown throughout the sarcoplasm while the nuclei were not labeled. No variation in either intensity or distribution of the staining was observed within the myocyte population isolated $4 \mathrm{~d}$ after aortic stenosis when compared with the controls (Fig. 7, $B$ and $E$, vs. $A$ and $D$ ).

\section{Discussion}

Until now, analysis of protein synthesis in the overloaded heart has been mainly quantitative and dealt with either total proteins $(6,28,29)$ or the major sarcomeric proteins $(30,31)$. Analysis of the in vivo synthesis of the less abundant proteins was hampered by the low level of their labeling despite the continuous infusion of a radioactive precursor for several hours (6). In vitro translation of cardiac mRNA was the first method that allowed the identification of minor polypeptides in the heart $(12,13,32)$. However, this method is believed to measure the relative abundance of translatable mRNAs and 


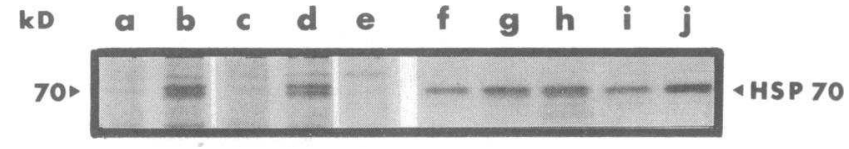

Figure 6. Immunological identification of the HSP 70 in myocardial cells whatever the level of synthesis of the protein. Labeled cardiac myocyte proteins were separated by 5-10\% linear gradient acrylamide SDS-gel electrophoresis and were detected by fluorography $(a-e)$ or immunoblot analysis using anti-HSP 70 antibodies $(f$ to $j$ ). Shown is a part of the original gel limited to the $70-\mathrm{kD}$ region. $a, f$ : sham-operated rat; $b, g$ : aortic stenosis $(2 \mathrm{~d}) ; c, h$ : aortic stenosis (15 d); $d, i$ :aortic insufficiency $(4 \mathrm{~d}) ; e, j$ : aortic insufficiency $(15 \mathrm{~d})$. Identical amounts of radioactivity were run in lanes $a-e$ and identical amounts of proteins were run in lanes $f-j$.

eliminates the possible translational controls specific to cardiac tissue. The model of isolated adult myocytes incubated with $\left.{ }^{35} \mathrm{~S}\right]$ methionine has enabled us to obtain a rapid (30 min) and high labeling of the myocyte proteins $(\sim 1,000 \mathrm{cpm} / \mu \mathrm{g}$ protein). In these conditions a larger number of polypeptides than those observed after the cell-free translation of whole cardiac mRNA $(12,13)$ were labeled and these probably represent proteins with a high rate of synthesis.

It emerged from this study that transient qualitative alterations in protein synthesis were associated with the early response of myocytes to a 2-4 d overload; the increased rate of synthesis of a group of neutral and acidic proteins was concomitant with the transient increased synthesis of a set of basic proteins that share the electrophoretic characteristics of ribosomal proteins $(22,27)$ and a transient decreased synthesis of a series of proteins including LC1. An increase in the synthesis of ribosomal RNA has also been described during this period by others (33), and a decrease in the relative rate of synthesis of LC1 compared with that of myosin heavy chains has been reported in overloaded guinea pig hearts by Evans et al. (34). Diastolic overload also induced a relative decrease in the synthesis of myofibrillar proteins (Fig. 3). The fact that the labeling of some proteins is decreased does suggest that the enhanced HSP labeling is not simply an artifact of increased $\left[{ }^{35} \mathrm{~S}\right]$ methionine transport. It is not our purpose to discuss these data since our experimental model is not adequate to deal with the still controversial question relating to the time
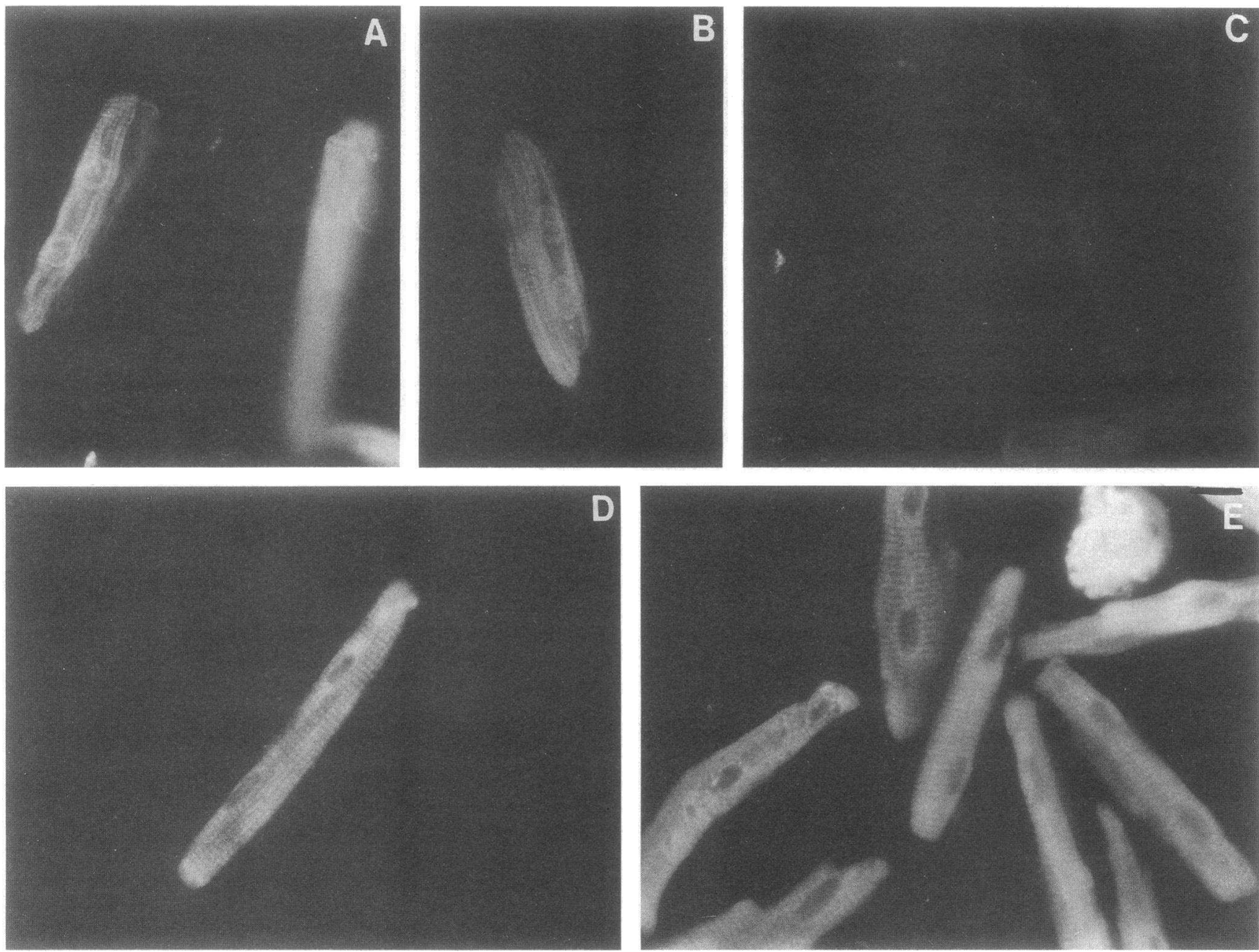

Figure 7. HSP 70 immunolabeling of cardiac myocytes isolated from sham operated rat $(A$ and $D)$ and from rat, $4 \mathrm{~d}$ after aortic stenosis $(B$ and $E$ ). Myocytes were stained either after methanol fixation ( $A$ and $B)$ or after Triton X-100 treatment $(D$ and $E)$. In C, the incubation

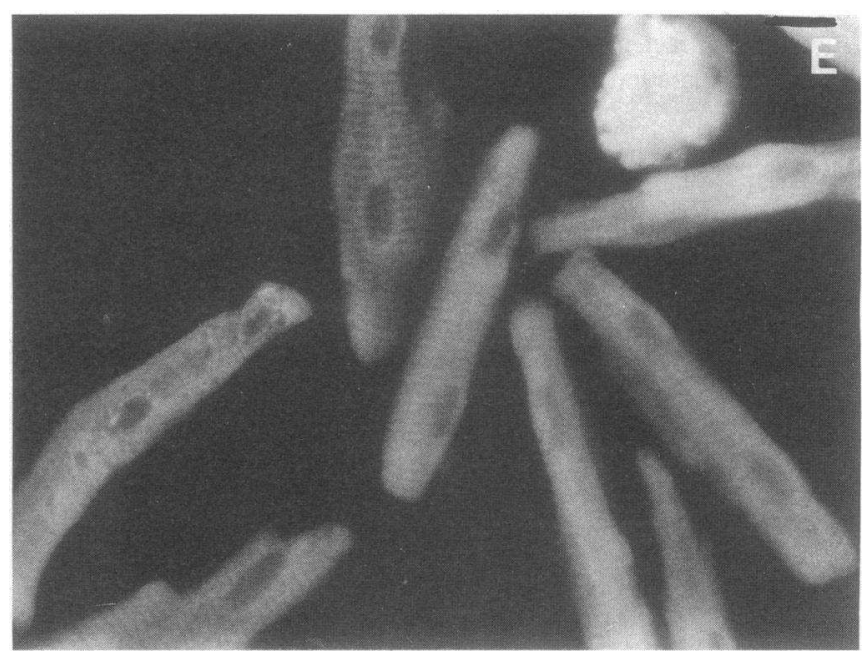

with specific anti-HSP $70 \mathrm{IgG}$ was omitted. Note that the HSP 70 pattern is homogeneous among the myocytes from overloaded heart and is similar to those of sham-operated rat. Bar, $10 \mu \mathrm{m}$. The intense labeling observed at the level of the round cell is not significant (25). 
course of the relative rate of synthesis and degradation of myofibrillar proteins during developing cardiac hypertrophy $(28,35,36)$. As a matter of fact the apparent "decrease" in the labeling of certain proteins could also be artifactual. Since the total protein specific activity (in counts per minute per microgram) was higher in hypertrophied cells, the decreases in apparent radiographic density could be due simply to less protein having been spotted without a change in the specific activity of the protein (as an example see Fig. 3). Indeed, it emerged from this study that the association of three qualitative alterations in peptide synthesis is a sensitive criterion for the identification of the early phase of active growth of cardiac myocytes secondary to hemodynamic overload.

We show in this study that these qualitative alterations were regularly associated with the enhanced expression of proteins identified as stress proteins. Since in mammals, stress proteins have mainly been reported to be expressed as a result of trauma $(37,38)$, we verified that these proteins were poorly synthesized in myocytes isolated from sham-operated rats or controls. It emerges from Table I and Fig. 6 that increased synthesis of HSPs was related neither to surgery nor to the isolation procedure, or the rounding of cells during incubation. No synthesis of HSPs was observed 7 or $21 \mathrm{~d}$ after aortic stenosis despite a relative decrease in the percentage of rodshaped cells, which was in the same range 2 and $4 \mathrm{~d}$ after aortic stenosis.

In the myocardium, the synthesis of HSP 70 , the most highly conserved stress protein, has been described after various traumas such as hypoxia $(11,39)$, ischemia (13), and heat shock of either the whole organ (12) or cultured cells from neonatal heart (37). More related to this work is that the expression of HSP 70 as assessed by translation of the mRNA was described as occurring $1 \mathrm{~h}$ after a severe aortic stenosis (12) and $3 \mathrm{~h}$ after a progressive overload (40). The aortic banding method that we used in this study is well known to induce a progressive hypertrophy of rat heart within 15 to $30 \mathrm{~d}(10,40)$, and was thus less severe than in Hammond's study (12). In the present work HSP 70 was identified by both immunological criterion and expression after a heat shock. Furthermore, the transient and early expression of the protein after both pressure and volume overload was shown to be associated with that of two other HSPs of 68 and $58 \mathrm{kD}$, which were previously described in other tissues (see 41 for a review) but not in cardiac muscle. It should be noted that HSP 70 was always present in cardiac myocytes, and that hemodynamic overload mainly induced an increase in the level of HSP synthesis (Figs. 4 and 6 ).

Moreover, this study provides evidence that the HSPs expressed in adult cardiac muscle are synthesized by myocytes. This fact is important since it was demonstrated that nonmuscle cells such as fibroblasts, possess a high ability to synthesize a large series of HSPs (23), whereas the ability of muscle cells to synthesize these proteins diminishes with differentiation (42). As a matter of fact, the enhanced expression of three HSPs by myocytes as a result of overload occurred at a period when other transient biochemical events develop: increase in protein degradation (30), expression of skeletal $\alpha$-actin mRNA (5), cellular remodelings such as the reorganization of microtubules (26), or multiplication of mitochondria (7). Interestingly, HSPs have been recently described as actin-binding proteins in nonmuscle cells (43) and as being associated to microtubules (44).
Stress proteins expressed as a result of heat shock were demonstrated to accelerate the recovery of damaged nucleoli, and to rescue protein synthesis $(45,46)$ and mRNA splicing (47) that had been interrupted during the stress. Here enhanced synthesis of stress proteins observed soon after imposition of hemodynamic overload appears to be enhanced concomitantly with total protein synthesis activity.

Cellular hypoxia, a potent inducer of stress protein synthesis (39, reviewed in 41 ), induces in the whole heart a decrease of total protein synthesis (28). Because the expression of HSPs in myocytes from overloaded hearts was, as described above, associated with an increase in total protein synthesis, it could be hypothesized that HSPs are specifically expressed by a subpopulation of damaged myocytes. Such a population was observed 2-4 d after hemodynamic overload by Hatt (48). However, this hypothesis does not fit with the results of immunocytochemical labeling of HSP 70 that failed to depict any emergence of a new myocyte population that exhibited changes in its cellular distribution after hemodynamic overload (Fig. 7). In cultured cells, the HSP 70 primarily distributed within cytoplasm was shown to rapidly migrate during heat shock from the cytoplasm to the nucleus $(23,45)$ however, these changes in HSP distribution depend on stress intensity and the addition of multiple stresses (23).

We have described in this study the early and transient expression of three HSPs in adult myocytes obtained from rat hearts submitted to a hemodynamic overload in vivo. The function of the HSPs in hypertrophying cardiac muscle and the identification of the trigger(s) for their induction have now to be elucidated.

\section{Acknowledgments}

We thank Dr. M. J. Schlesinger for kindly providing the anti-HSP 70 antibodies, Dr. A. Barrieux and Dr. B. Swynghedauw for helpful discussion and comments on the manuscript, Dr. G. Butler Brown for editorial help, and P. Cagnac and R. Houssin for secretarial assistance.

This work was supported by the Institut National de la Santé et de la Recherche Médicale, the Centre National de la Recherche Scientifique, and the Caisse Nationale d'Assurance Maladie des Travailleurs Salaries.

\section{References}

1. Swynghedauw, B., and C. Delcayre. 1982. Biology of cardiac overload. Pathobiol. Ann. 12:137-183.

2. Schreiber, S. S., M. Orats, M. A. Rothschild, and F. Reff. 1978. Effect of hydrostatic pressure on isolated cardiac nuclei: stimulation of RNA polymerase II activity. Cardiovasc. Res. 12:265-268.

3. Hatt, P. Y., L. Ledoux, and J. P. Bonvalet. 1965. Lyse et synthèse des proteines myocardiques au cours de l'insuffisance cardiaque expérimentale. Arch. Mal. Coeur Vaiss. 58:1703-1721.

4. Izumo, S., A. M. Lompre, R. Matsuoka, G. Koren, K. Schwartz, B. Nadal-Ginard, and V. Mahdavi. 1987. Myosin heavy chain mRNA and protein isoform transitions during cardiac hypertrophy. J. Clin. Invest. 79:970-977.

5. Schwartz, K., D. de la Bastie, P. Bouveret, P. Oliviero, S. Alonso, and M. Buckingham. 1986. $\alpha$-skeletal muscle actin mRNA's accumulate in hypertrophied adult rat hearts. Circ. Res. 59:551-555.

6. Moalic, J. M., J. Bercovici, and B. Swynghedauw. 1981. Protein synthesis during systolic and diastolic cardiac overloading in rats: a comparative study. Cardiovasc. Res. 15:515-521.

7. Albin, R., R. T. Dowell, R. Zak, and M. Rabinowitz. 1973. Synthesis and degradation of mitochondrial components in hypertrophied hearts. Biochem. J. 136:629-637. 
8. Watkins, S. C., J. L. Samuel, F. Marotte, B. Bertier-Savalle, and L. Rappaport. 1987. Microtubules and desmin filaments during the onset of heart hypertrophy in rat: a double immunoelectron microscope study. Circ. Res. 60:327-336.

9. Jouannot, P., and P. Y. Hatt. 1975. Rat myocardial mechanics during pressure-induced hypertrophy development and reversal. Am. J. Physiol. 229:355-364.

10. Bugaisky, L. B., E. Siegel, and R. G. Whalen. 1983. Myosin isozyme changes in the heart following constriction of the ascending aorta. FEBS (Fed. Eur. Biochem. Soc.) Lett. 161:230-234.

11. Currie, R. W., and F. P. White. 1981. Trauma-induced protein in rat tissues: a physiological role for a "heat shock protein"? Science (Wash. DC). 214:72-73.

12. Hammond, G. L., Y. K. Lai, and C. L. Markert. 1982. Diverse forms of stress lead to new pattern of gene expression through a common and essential metabolic pathway. Proc. Natl. Acad. Sci. USA. 79:3485-3488.

13. Dillmann, W. H., H. B. Mehta, A. Barrieux, B. D. Guth, W. E. Neeley, and J. Ross, Jr. 1986. Ischaemia of the dog heart induces the appearance of a cardiac mRNA coding for a protein with migration characteristics similar to heat-shock/stress protein 71. Circ. Res. 59:110-114.

14. Burdon, R. H. 1986. Heat shock and the heat shock proteins. Biochem. J. 240:313-324.

15. Schlesinger, M. J. 1986. Heat shock proteins: the search for functions. J. Cell Biol. 103:321-325.

16. Eckel, J., G. Pandalis, and H. Reinauer. 1983. Insulin action on the glucose transport in isolated cardiocytes from adult rat. Biochem. $J$. 212:385-392.

17. Sommer, J. R., and E. A. Johnson. 1979. Ultrastructure of cardiac muscle. In Handbook of Physiology, section 2. The Cardiovascular System. Vol. I, section 2. R. M. Berne, N. Sperelakis, and S. R. Geiger, editors. Am. Physiol. Soc. Washington D.C. 113-186.

18. Claycomb, W. C. 1985. Long-term culture and characterization of the adult ventricular and atrial cardiac muscle cell. Basic Res. Cardiol. 80(Suppl. 2):171-174 and discussions 196-197.

19. Altschuld, R. A., W. C. Wenger, and G. P. Brierley. 1985. Ionic movements and irreversible anoxic damage. Basic Res. Cardiol. 80(Suppl. 2):151-154 and discussions 196-197.

20. Lowry, O. H., N. J. Rosenbrough, A. L. Farr, and J. Randall. 1951. Protein measurement with the folin phenol reagent. J. Biol. Chem. 193:265-275.

21. Laemmli, U. K. 1970. Cleavage of structural proteins during the assembly of the head of bacteriophage T4. Nature (Lond.). 227:680-685.

22. O'Farrell, P. Z., H. M. Goodman, and P. H. O'Farrell. 1977. High resolution two-dimensional electrophoresis of basic as well as acidic proteins. Cell. 12:1133-1142.

23. Collier, M. C., and M. J. Schlesinger. 1986. The dynamic state of heat shock proteins in chicken embryo fibroblasts. J. Cell Biol. 103:1495-1507.

24. Towbin, H., T. Staehelin, and J. Gordon. 1979. Electrophoretic transfer of proteins from polyacrylamide gels to nitrocellulose sheets: procedure and some applications. Proc. Natl. Acad. Sci. USA. 76:4350-4354.

25. Samuel, J. L., L. Rappaport, J. J. Mercadier, A. M. Lompre, S. Sartore, C. Triban, S. Schiaffino, and K. Schwartz. 1983. Distribution of myosin isozymes within single cardiac cells. An immunohistochemical study. Circ. Res. 52:200-209.

26. Samuel, J. L., B. Bertier, L. Bugaisky, M. Marotte, B. Swynghedauw, K. Schwartz, and L. Rappaport. 1984. Different distributions of microtubules, desmin filaments and isomyosins during the onset of cardiac hypertrophy in the rat. Eur. J. Cell Biol. 34:300-306.

27. Wool, H. J. 1979. Structure and function of eukaryotic ribosomes. Annu. Rev. Biochem. 48:719-754.

28. Schreiber, S. S., C. D. Evans, M. Oratz, and M. A. Rothschild.
1981. Protein synthesis and degradation in cardiac stress. Circ. Res. 48:601-611.

29. Kira, Y., P. J. Kochel, E. E. Gordon, and H. E. Morgan. 1984. Aortic perfusion pressure as a determinant of cardiac protein synthesis. Am. J. Physiol. 246:C247-C258.

30. Morkin, E., S. Kimata, and J. J. Skillman. 1972. Myosin synthesis and degradation during development of cardiac hypertrophy in the rabbit. Circ. Res. 30:690-702.

31. Moalic, J. M., J. Bercovici, and B. Swynghedauw. 1984. Myosin heavy chain and actin fractional rates of synthesis in normal and overload rat heart ventricles. J. Mol. Cell. Cardiol. 16:875-884.

32. Dillmann, W. H., A. Barrieux, W. E. Neeley, and P. Contreras. 1983. Influence of thyroid hormone on the in vitro translational activity of specific mRNAs in the rat heart. J. Biol. Chem. 12:7738-7745.

33. Ray, A., M. C. Aumont, J. Aussedat, J. Bercovici, A. Rossi, and B. Swynghedauw. 1987. Protein and $28 \mathrm{~S}$ ribosomal RNA fractional turnover rates in the rat heart after abdominal aortic stenosis. Cardiovasc. Res. 21:587-592.

34. Evans, C., S. S. Schreiber, M. Oratz, and M. A. Rothschild. 1978. Synthesis of myosin heavy and light chains in the afterloaded guinea pig right ventricle. Cardiovasc. Res. 12:731-743.

35. Zimmer, H. G., G. Steinkopf, and E. Gerlach. 1972. Changes of protein synthesis in the hypertrophying rat heart. Pfluegers Arch. Eur. J. Physiol. 336:311-325.

36. Moalic, J. M., and B. Swynghedauw. 1987. Regulation of gene expression in normal and overload heart. In Stress Heart. M. Legato, editor. Martinus Nijoff Publ., Boston, MA. 1-19.

37. Hightower, L. E., and F. P. White. 1982. Preferential synthesis of rat heat shock and glucose-regulated proteins in stressed cardiovascular cells. In Heat Shock: from Bacteria to Man. M. J. Schlesinger, M. Ashburner, and A. Tissieres, editors. Cold Spring Laboratory, Cold Spring Harbor, NY, 369-377.

38. White, F. P., and R. W. Currie. 1982. A mammalian response to trauma: the synthesis of a $71-\mathrm{kDa}$ protein. In Heat Shock: from Bacteria to Man. M. J. Schlesinger, M. Ashburner, and A. Tissieres, editors. Cold Spring Laboratory, Cold Spring Harbor, NY. 379-387.

39. Howard, G., and T. E. Geoghegan. 1980. Altered cardiac tissue gene expression during acute hypoxic exposure. Mol. Cell. Biochem. 69:155-160.

40. Ende, D. Y., A. F. Martin, S. Jakovcic, and R. Zak. 1987. Induction of $\mathrm{HSP}_{70}$ stress protein mRNAs during cardiac hypertrophy. J. Am. Coll. Cardiol. 9:38A. (Abstr.)

41. Subjeck, J. R., and T. T. Shyy. 1986. Stress protein systems of mammalian cells. Am. J. Physiol. 250:C1-Cl7.

42. Atkinson, B. G. 1981. Synthesis of heat-shock proteins by cells undergoing myogenesis. J. Cell Biol. 89:666-673.

43. Koyasu, S., E. Nishida, T. Kadowaki, F. Matsuzaki, K. Iida, F. Harada, M. Kasuga, H. Sakai, and I. Yahara. 1986. Two mammalian heat shock proteins, HSP 90 and HSP 100 are actin-binding proteins. Proc. Natl. Acad. Sci. USA. 83:8054-8058.

44. Clark, B. D., and I. R. Brown. 1986. A retinal heat shock protein is associated with elements of the cytoskeleton and binds to calmodulin. Biochem. Biophys. Res. Commun. 139:974-981.

45. Welch, W. J., and J. P. Suhan. 1985. Morphological study of the mammalian stress response: characterization of changes in cytoplasmic organelles, cytoskeleton, and nucleoli, and appearance of intranuclear actin filaments in rat fibroblasts after heat-shock treatment. J. Cell Biol. 101:1198-1211.

46. Pelham, H. R. B. 1984 . Hsp 70 accelerates the recovery of nuclear morphology after heat shock. Eur. Mol. Biol. Org. J. 3:30953100.

47. Yost, H. J., and S. Lindquist. 1986. RNA splicing is interrupted by heat shock and is rescued by heat shock protein synthesis. Cell. 45:185-193.

48. Hatt, P. Y. 1977. Cellular changes in mechanically overloaded heart. Basic Res. Cardiol. 72:198-202. 